\title{
Profile of Contributors of University Radio in Spain: The Case of Students in the Area of Information Science
}

\author{
Daniel Martín Pena ${ }^{1}$, Ana Segura Anaya ${ }^{2}$, Carmen Marta Lazo ${ }^{2}$ \\ ${ }^{1}$ University of Extremadura, Badajoz, Spain \\ ${ }^{2}$ University of Zaragoza, Zaragoza, Spain \\ Correspondence: Daniel Martín Pena, Facultad Ciencias de la Documentación y la Comunicación, University of \\ Extremadura, Plazuela Ibn Marwan s/n, 06071, Badajoz, Spain.
}

Received: November 3, 2015 Accepted: November 9, 2015 Online Published: November 30, 2015

doi:10.11114/smc.v3i2.1228

URL: http://dx.doi.org/10.11114/smc.v3i2.1228

\begin{abstract}
This article examines the reality of Spanish university radio, a relatively recent and poorly studied reality (only 40 years since Radio UNED began its first recordings). University radio in Spain is very heterogeneous and diverse, these features are clearly reflected in one of the parameters of analysis of this phenomenon; the profile of its contributors and / or participants. In this sense, Spanish university radio agglutinates a wide range of possibilities, from broadcasters who make their broadcats available to the university community as a whole (Professor-Research, university staff and students) as well as to the rest of society, building bridges with them and bringing about the participation of anonymous citizens, associations or NGOs. At the other extreme, there are radio stations that only allow the participation of students from the area of information science, configuring them as authentic practical platforms for these students, and they receive additional training that may be essential in order to gain access to the labour market. This has been evident on many occasions, and we have corroborated this in interviews carried out with various partners and those in charge of the stations.
\end{abstract}

Keywords: profile, Spanish University Radio, information science

\section{Introduction: University Radio in Spain}

It was during the 70's when programs linking the two realities, radio and university arose. As Ortiz (2012: 16) says there were radio professionals who "believed that universities and university students had much to say and contribute to this means of communication." There are several stations of a conventional kind that set in motion programs like " University Time", "Open tap " or "Evenings of Inter" in which the real protagonists are the university students, in this case, students of the Faculty of Information Sciences at the Complutense University.

The first station we consider to be the initiator of the movement of University radio in Spain is Radio San Fernando (currently Campus Radio) at the University of La Laguna, which was launched in 1987 through the efforts and initiative of students living in the San Fernando hall of residence. But it is noteworthy that 13 years earlier, in 1974 the first educational recordings from an institution of higher education, the National University of Distance Education, which uses frequencies of National Radio of Spain in its different channels) began. These frequencies allowed it to reach the whole country, and therefore all their students, since the main purpose of this station was none other than supporting education provided by its faculty, from a distance (Martín-Pena \& Ortiz, 2014). Martin-Pena stated in several of his publications $(2013,2014)$ that there are 3 stages of development of university radio stations in Spain:

- Phase 1 (appearance and initiation of the first ones): This phase, until the late twentieth century, is marked by a slow and sluggish (with many starts and stops) development, and as we have noted there were very few universities which began their transmissions, some significant ones were Complutense Radio, University of Salamanca Radio or 98.3 Radio. No more than ten of them, some of which have already disappeared.

- Phase 2 (consolidation and expansion of the phenomenon): This period covers the first decade of the XXI century, an authentic boom movement, in just over ten years there arose more than fifteen stations, thanks to:

- Development of Information and Communication Technologies; which made possible considerable progress in the law and economics facilities for the launching of a university radio project. 
- Platform for work experience for studies in the area of the CCII; the universities which had studies in these areas began to observe the practical use of radio stations for offering a well rounded education to their students.

- Drawing closer to society; it is obvious that universities should look at society, and university radio stations began to constitute an appropriate channel of understanding between both realities.

- The beginning of cooperative networking; in 2003 meetings began among the heads of the radio stations, causing the emergence of a spirit of cooperation and collaborative work.

- Phase 3 (rethinking and uniting the phenomenon): This phase is in full swing today and is marked by the economic crisis affecting Spanish society in general and the university in particular. This is why university radio stations are experiencing some difficult moments and faced with this situation the stations have succeeded for the first time in their 30 year history, by forming a network, in creating the Association of University radio stations in Spain (ARU). This association was established during the celebration of the seventh meeting in June 2011 in Badajoz (University of Extremadura). In recent years, only 3 stations have appeared; and they all have a common denominator, which is that all of them are in universities which offer communication studies and with the support and development of ICT through hypermedia platforms that offer a complete formation to students of information science.

Currently, in Spain there are approximately 30 universities radio stations, both FM, as well as streaming or podcast, which are functioning in our universities. Of these 30 stations, 23 of them belong to the ARU. This fact means that in one in three Spanish universities there is a university radio project (Martín-Pena \& Contreras, 2014).

\section{The Contributors of the University Stations}

Many authors (Contreras, Gonzalez \& Aguaded, 2014; Martín-Pena, 2013; Fidalgo 2009) point out that an important feature of Spanish university radio is its great heterogeneity. This concept was present from the very beginning of the radio project, i.e. stations whose main objective was to offer internships to students with degrees related to the world of communication or as a place for research and experimentation of new formats. Another objective was to represent the university by offering free access to the entire university community and even to connect with society. In this sense, the existence of a university radio bases most of its success on the ability to attract both the university and non-university community, in front of the microphones and behind them, i.e. not only as passive listeners, but as active transmitters and participatory receivers. Vázquez (2012: 69) notes that starting from each station's own models we can gain a rough idea of the participation of each of them, as there are stations for different purposes, ranging from those that offer student work experience to those which serve as a forum of expression for the university community, as well as the stations that are more institutional and less open, and stations which operate as experimental laboratories for new forms and content. In the Spanish case, most of these stations allow participation which is extremely open to all, this fact is reflected in the rules of operation of several stations, which advocate that a broad and diverse range of people can contribute to the elaboration of the radio's content; one example is the case of OndaCampus in the University of Extremadura. As can be seen on its website (www.ondacampus.es) these are the groups that can use university radio: - Students studying a Degree in Audiovisual Communication.

- Students from the four campuses of the University of Extremadura.

- Administration and Services Personnel.

- Teaching and Research Personnel.

- Research Groups.

- Services or Units of the organic structure of the UEX.

- Collectives, social groups or individuals who wish to be involved.

The section of other contributors includes associations, groups, NGOs or social and / or civilian groups, who find in university radio a form of expression or protest not offered by conventional stations, which are more concerned about achieving goals of another kind.

In this sense, as Vázquez (2012: 115) points out, it is common for university radio with a more social profile and of public service to emit their broadcasts far beyond the walls of the campus. Not all university radio in Spain is characterized by having such a wide range of collaborators. In other universities the range is a little more restricted, but the standard pattern is always the same, a strong and young student presence.

\subsection{Students and Young People as a Wakeup Call}

In an exploratory study conducted in 2001 by Livia Van der Graaf (2001: 20-21), who analyzed the features of eleven university radio stations run by young students in Spain, Belgium, Britain and France, he noted that: "Student radio stations function as training, information, meeting and entertainment tools. It is important that students can learn to 
make radio professionally, have a means to express themselves and that people can listen to them. Therefore, freedom of expression and opinion holds a special place in student radio. To be free to give and exchange their opinions is essential for healthy understanding among young people, and between them and society in general".

It is clear that youth has a key role in the development of Spanish university radio. In this sense, Vazquez in several studies carried out in 2010 , calculates this youthful presence in $81 \%$ (of this percentage $92 \%$ are students from the institution itself), noting that this group is in the majority in radios with student and mixed models and smaller in institutionalized models, in which the degree of participation is much lower.

These stations, which are happy to fully involve young people, shatter the myth that students do not want to participate in university life; because when ways to participate are provided, students respond, and become part of day-to-day university life.

But we must not forget what was noted by Martin-Pena (2013) who reminds us that in Spain we find few stations run by professionals, they have staff who in general have precarious contracts, and even stations which operate at zero cost and thanks to the good will of their collaborators. These are mostly young people who approach this media in order to complete their formation in information science or to express their concerns.

\subsection{Profile of External Collaborators}

One of the concepts to which this type of station has been linked, since some years ago, was public service and its social nature. Several authors such as (Aguaded \& Contreras, 2011; Aguaded \& Martin-Pena, 2013 and Marta \& Martin-Pena, 2014) defend the premise that these stations perform tasks of public service, giving voice to the voiceless, i.e., opening the airwaves to members who do not belong to the university community but who have much to contribute to social debate and that no other radio station offers them that possibility. In this section about other collaborators or external collaborators who are not part of the university are included associations, groups, NGOs or social or civil collectives, which find in university radio a voice of protest or expression which is closed to them in conventional stations

For Aguaded \& Contreras (2011), the ideal model of a university radio is one in which the radio generates knowledge, offers a social transfer, contains social advertising, plays a humanistic role and develops supportive and cooperative purposes with a team spirit. As Martin-Pena (2013: 189) points out, social organizations that need the help of university radio stations to broadcast their activities are numerous, and university radio is the only means for them to publicize their work.

With these initiatives university radio shows that its commitment to the formation of citizens, and to offering alternative content to commercial broadcasters and the promotion of scientific culture, is real.

\section{The Students of Information Science}

When we speak of the profile of radio station collaborators a special mention should be made about students following disciplines related to Information Science (Journalism, audiovisual communication, advertising and public relations, and even new degrees that address similar issues in a digital and transmedia context). In this regard, we must stress that university radio is a means which constitutes an ideal complementary formation for student's studying in the area of information science, and aimed at professional training which is much closer to real work situations. In the same vein, Araya (2009), notes that the fact that many stations are used as laboratories for learning how to work in the radio medium is a very common feature in the reality of these stations. This formative function fits the purposes attributed to the University by the Organic Law of Universities; if we understand audiovisual media as an educational environment, university radio, in particular, "is presented as a space where students can gain experience in addition to formal education and acquire skills and values." The participation of these students is often essential in the development of projects of this nature, but it is necessary to establish coordination mechanisms for such participation to be successful (Álvarez \& Ramirez, 2005).

In the case of Spain, it can be seen that most of the stations are developed in universities with some kind of studies related to information science (Espino \& Martin, 2012: 287-297). This is verified by Piñeiro \& Ramos (2011: 97), who point to the fact that many university radios arose within the communication faculties, with the intention of setting up procedures which are as real as possible for enrolled students. In this sense, as Marta \& Segura (2012: 120) noted, most of the stations have related information science studies which draw on the radio experience undertaken by their students. One of the stations which is a reference in these issues is the University of Navarra radio station, the 98.3 Radio, which has been and is an important part of the studies related to information science that are taught at the university, because it is a valuable means for students interested in enhancing the practical skills necessary for their future professional performance. As Vázquez (2012: 102-140) points out, this station has a very advanced pedagogical model which is a mix of comprehensive training and professional media. It is a pioneer in integrating students in the production of programs and in linking student practice with the professional world. 
Many authors point out that such stations are the best practical tool for these students (Sauls, 1995; Desztich \& McLung, 2007).

This experience improves their confidence, their potential, their level of competence and initiative, and makes them feel prepared for working life in the specialty they themselves have chosen (Ceballos et al, 2010). For Parejo \& Martin-Pena (2011: 136-138), these students, thanks to the existence of university radio, have been able to gain work experience in various areas, involving production of a radio program: writing, speech, presentation, technical production, post-production, website management ... and at the same time, these future professionals of communication have learnt about the difficulties and responsibilities that are part of each of the cited profiles.

\section{Methodology}

After having shown the current situation in Spain, we now proceed to analyze specifically the presence of the different collaborator types in Spanish university radio stations. To do this we have analyzed 24 university radio stations that belong to the Association of University Radio of Spain, which accounts for $80 \%$ of radio stations in the country. It is appropriate to note that in 16 of those 24 stations we have located studies of information and communication, some with direct links to them and others not; and using this data we corroborate what we have stated above that most stations arise under the umbrella of these disciplines, and are a direct consequence of the expansion of the phenomenon in the early part of this century.

Table 1. Spanish University Radio belonging to ARU (Asociación Radios Universitarias de España)

\begin{tabular}{ll}
\hline Radio Station & \multicolumn{1}{c}{ University } \\
\hline 98.3 Radio* & University of Navarra \\
Europea Radio* & University Europea de Madrid \\
Inforadio* & University Complutense de Madrid \\
iRadio UCAM* & University Católica San Antonio Murcia \\
OnCEU Radio* & University CEU San Pablo Madrid \\
OndaCampus Radio* & University of Extremadura \\
Radio Campus & University of La Laguna \\
Radio CEU* & University CEU Cardenal Herrera Valencia \\
Radio SIDE & University Cantabria \\
Radio UMH* & University Miguel Hernández de Elche \\
Radio UNED & University Nacional de Educación a Distancia \\
Radio Universidad San Jorge* & University San Jorge \\
Radio Universidad* & University of Salamanca \\
Radio Universidad.es & University of Almería \\
Radio Universitaria & University of León \\
Radio Universitat de València* & Universitat of València \\
Radio Unizar* & University of Zaragoza \\
Radio URJC* & University Rey Juan Carlos \\
RUAH Alcalá & University Alcalá de Henares \\
UniRadio Huelva & University of Huelva \\
UniRadio Jaén & University of Jaén \\
UPF Ràdio* & University Pompeu Fabra \\
UPV Radio* & University Politècnica de València \\
Vox UJI Ràdio* & University Jaume I \\
\hline ble 1, the detailed research sample. * Stations with studies of information science
\end{tabular}

As shown in Table 1, the detailed research sample. ${ }^{*}$ Stations with studies of information science

\section{Results of the Presence of Collaborators in the Stations of the ARU}

In the stations we have analyzed we have detected all the possible profiles that we have mentioned throughout this work, both within the university community (Professor-research, university staff and students) and outside of it, i.e., associations or anonymous people for whom university radio stations are a voice that is denied them on radio of a commercial type, which is more concerned with commercial ends. Thus, the role of service to citizens, which university type radio stations play, is clearly demonstrated. It is a fact that half of ARU stations (twelve) provide access to this type of profile as a producer of content, making university radio stations, not only a reflection of the reality of life in the classroom, but also a mirror of a city or society that welcomes the institution of higher education. Regarding the other half i.e. stations that do not have external partners, a total of eight (67\%) correspond to university stations with degrees related to the area of communication. The positive news, which demonstrates the level of diversity and openness that these stations are acquiring, is that in almost half of the stations (46\%) we have found all profiles present in the production of radio programs, taking into account that four of these eleven stations do not fit the profile regarding students of information science because these studies are not offered by their respective universities. 


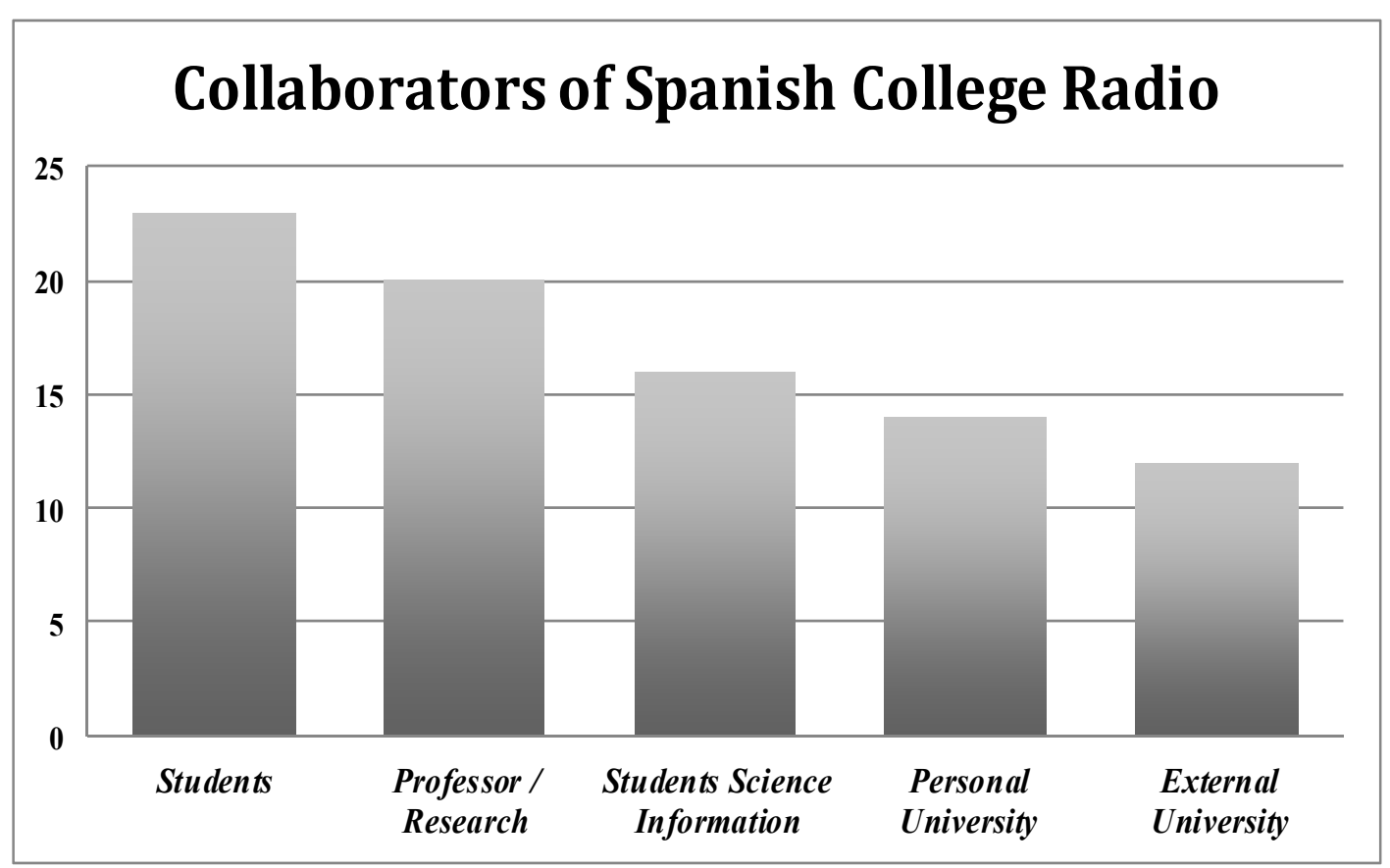

Figure 1. Collaborators in Spanish University Radios

As shown in Figure 1, the groups of collaborators presents in 24 Spanish university radios

Predictably, seeing as college radio is representative of the reality of the school, the majority partner profile is students (96\%); in fact 58\% of the stations (fourteen) have a majority of students who are studying information science, and of these, there are only three which restrict access to students from other areas, and even other collaborator profiles (Radio University, Radio and Radio UNIZAR USJ, stations that have emerged since 2011 linked to these studies). In nine other stations (38\%) the largest profile is students from other disciplines, leaving the professor-research as the majority profile in Radio UNED (4\%). Professor-research and university staff, in that order, have a much educed presence of collaborators of the Spanish university radio stations.

Another point to keep in mind in order to see the importance of these types of stations for students of information science is the number of partners that the different university radio stations have. In terms of collaborators, in the top ten positions we locate eight stations (33\%) involving students from information science, who are drawn directly from the student body (98.3 Radio or Radio CEU) or simply due to the interest shown by students in these areas to ensure better training to ensure access to the labour market. Among the ten stations leading this table are the UniRadio stations of Huelva and Jaen, both with large student participation and open to external partners, that expand and enrich their programming 
Table 2. Collaborators in Spanish University Radios

\begin{tabular}{|c|c|c|c|c|c|}
\hline $\begin{array}{l}\text { Radio } \\
\text { Station }\end{array}$ & $\begin{array}{c}\text { Students } \\
\text { Information Science }\end{array}$ & $\begin{array}{c}\text { Other } \\
\text { Students }\end{array}$ & $\begin{array}{l}\text { Professors- } \\
\text { Research }\end{array}$ & $\begin{array}{c}\text { University } \\
\text { Staff }\end{array}$ & Externals \\
\hline Radio UNED & & & $\mathrm{X}$ & & $\mathrm{X}$ \\
\hline Radio Campus & & $X$ & $X$ & $\mathrm{X}$ & $X$ \\
\hline InfoRadio UCM* & $\mathrm{X}$ & $X$ & $X$ & $\mathrm{x}$ & \\
\hline Radio USAL* & $X$ & $X$ & $X$ & $\mathrm{x}$ & $X$ \\
\hline 98.3 Radio* & $\mathrm{X}$ & $\mathrm{X}$ & $\mathrm{X}$ & $\mathrm{x}$ & $\mathrm{X}$ \\
\hline Radio León & & $X$ & $X$ & & \\
\hline Europea Radio* & $\mathrm{X}$ & $X$ & $X$ & & \\
\hline UPV Ràdio* & $\mathrm{X}$ & $X$ & $X$ & $x$ & $X$ \\
\hline Vox UJI Ràdio* & $x$ & $X$ & $X$ & $x$ & $X$ \\
\hline OndaCampus Radio* & $\mathrm{X}$ & $X$ & $X$ & $\mathrm{X}$ & $X$ \\
\hline Radio CEU & $\mathrm{X}$ & $X$ & $X$ & & \\
\hline \multicolumn{6}{|l|}{ Valencia* } \\
\hline UniRadio Huelva & & $X$ & $X$ & $\mathrm{X}$ & $\mathrm{x}$ \\
\hline UPF Ràdio* & $\mathrm{X}$ & $X$ & $X$ & $X$ & $X$ \\
\hline Radio UMH* & $X$ & $X$ & $X$ & $X$ & \\
\hline RUAH Alcalá & & $X$ & $X$ & $X$ & $X$ \\
\hline Radio URJC* & $\mathrm{X}$ & $X$ & $X$ & $X$ & $X$ \\
\hline iRadio UCAM* & $\mathrm{X}$ & $X$ & $X$ & & \\
\hline Radio Universidad.es & & $x$ & $x$ & $x$ & \\
\hline UniRadio Jaén & & $X$ & $x$ & $X$ & $X$ \\
\hline OnCEU Radio* & $\mathrm{X}$ & $X$ & & & \\
\hline Radio SIDE & & $x$ & $x$ & & \\
\hline Radio.UniZar.es* & $X$ & & & & \\
\hline Radio Universitat* & $x$ & & & & \\
\hline Radio USJ* & $\mathrm{X}$ & & & & \\
\hline
\end{tabular}

As shown in Table 2, the detailed data of the staff on the college radio. ${ }^{*}$ Stations with studies of information science

\section{Conclusions}

The main conclusion is that the presence of students in the daily life of university radio is clearly in the majority; It is a fact, as claimed by several authors gathered in the contextualization of this communication, that in all stations the student profile is imposed on professor-research and university staff. Whether students in the area of information science or in other areas of knowledge, this collective is the great mobilizing force and energizer of such stations in Spain. Moreover, it can be affirmed that the profile of students related with communication studies is in terms of numbers certainly overwhelming, since many of them are "forced" to participate in university radio as part of regulated practices, and another large percentage due to interest in complementing their study curricula. In addition we have found that due to the crisis affecting Spanish society in general and the media in particular, it is more difficult for graduates to enter the job market, which is why many of them choose to continue being linked voluntarily to the station for further education and pending entry into the business world.

It is of interest to observe how in half the radio stations we found external collaborators, which corroborates the social and public service nature that permeates these radios and should be of intrinsic value to them, and this has been defended by numerous authors who have been mentioned throughout this article. However, work remains to be done in terms of the internal profile, which refers to the university community. University radio stations have clearly gained ground among the students, but initiatives are necessary that will help bring the station to members of Universtiy Staff and Professor-Research, since their presence today, despite being represented in most stations, is quasi testimonial to the real number.

The great diversity of profiles connected with Spanish university radio clearly defines one of the main characteristics of these stations in this country, its marked heterogeneity. And the fact of the large number of future media professionals, students studying journalism or communication, who, on a daily basis, approach these stations, clearly shows the educational value these radio stations have for this group, so as to acquire the necessary skills to develop their future work in the mainstream media.

\section{Acknowledgements}

With the support of "Fondos FEDER. Programa operativo FEDER de Extremadura 2014-2020. Consejería de Economía e Infraestructuras. Junta de Extremadura. Ayuda para la realización de actividades de investigación y Desarrollo Tecnológico, de Divulgación y de Transferencia de conocimiento por los Grupos de Investigación de Extremadura" 


\section{References}

Aguaded, J. I., \& Contreras, P. (2011). (Coords). La radio universitaria como servicio público para una ciudadanía democrática. A Coruña: Netbiblo.

Aguaded, J. I., \& Martín-Pena, D. (2013). Educomunicación y radios universitarias: panorama internacional y perspectivas futuras. Revista Latinoamericana de Comunicación Chasqui, 124, 63-70. http://dx.doi.org/10.16921/chasqui.v0i124.20.g830

Álvarez, A., \& Ramírez, A. (2005). Los objetivos de las emisoras de radio universitarias a través de su programación. Paper presented at the Second Congreso Iberoamericano de Comunicación Universitaria, Universidad de Granada, España.

Araya, C. (2009). Radio Estudiantil: programas, audiencias y desafíos. Rev. Reflexiones, 88, 37-44.

Asuaga, C. (2007). Gestión de las radios universitarias: definiendo la estrategia. Revista RE-Presentaciones, 3, $185-196$.

Ceballos, J. J., Lemrini, M., Mateos, R. M., Vázquez, M. A., Barrero, J., \& Sánchez, J. (2010). UEMCOM Radio: Refuerzo de competencias mediante streaming y podcasting. Revista de Docencia Universitaria, 8(2), 45-72.

Contreras, P. (2012). La voz de los presos en la radio universitaria: puentes con la ciudadanía. La experiencia de UniRadio, Universidad de Huelva. En C. Espino Narváez \& D. Martín-Pena (coords.), Las radios universitarias, más allá de la radio. Las TIC como recursos de interacción radiofónica (153-165). Barcelona: Editorial UOC.

Contreras, P., González-Mairena, M., \& Aguaded, J. I. (2014). Programar una radio social en la universidad: el Propósito Penélope de UniRadio. EDMETIC, Revista de Educación Mediática y TIC, 3(1), 112-130.

Desztich, R., \& McClung, S. (2007). Why music gets added to college radio playlist. Journal of Radio y Audio Media, 14(2), 196-211.

Espino, C., \& Martín-Pena, D. (2012). (Coords). Las radios universitarias, más allá de la radio. Las TIC como recursos de interacción radiofónica. Barcelona: Editorial UOC.

Fidalgo, D. D. (2009). Las radios universitarias en España: Transformación al mundo digital. Telos, 80, $124-137$.

Magaña, L. S. (2003). El modelo de radio universitaria en Estados Unidos de Norteamérica: el caso de KTCU (Degree Thesis, Universidad de las Américas, Puebla, México). Retrieved from http://catarina.udlap.mx/u_dl_a/tales/documentos/lco/magana_1_sm

Marta, C., \& Martín-Pena, D. (2014). Antecedentes, estado de la cuestión y prospectiva de las radios universitarias. Revista de Educación Mediática y TIC (EDMETIC), 3(1), 2-7.

Marta, C., \& Segura, A. (2012). Emisoras universitarias españolas en la Web 3.0: programación y contenidos. En C. Espino Narváez \& D. Martín-Pena (coords.), Las radios universitarias, más allá de la radio. Las TIC como recursos de interacción radiofónica (103-124). Barcelona: Editorial UOC.

Martín-Pena, D. \& Aguaded, J. I. (2013). La Asociación de Radios Universitarias como eje dinamizador de intercambios para la divulgación científica. En P. Contreras \& M. Parejo (cords.), Más Ciencia. Cómo trabajar la divulgación científica desde las Radios Universitarias. (38-50). Salamanca: Comunicación Social.

Martín-Pena, D. (2013). Las radios universitarias en España: plataformas interactivas y redes de colaboración (Doctoral Thesis, Universidad de Huelva, España). http://hdl.handle.net/10272/7238

Martín-Pena, D., \& Ortiz Sobrino, M. A. (2014). Radios Universitarias en América y Europa. Madrid: Editorial Fragua.

Ortiz, M. A. (2012). “Presentación”. En C. Espino Narváez \& D. Martín-Pena (coords.), Las radios universitarias, más allá de la radio. Las TIC como recursos de interacción radiofónica (7-10). Barcelona: Editorial UOC.

Ortiz, M. A., \& Peña, P. (2010). Radio Intercontinental-Radio Inter: 60 años de radio. Revista de Comunicación Vivat Academia, 113, 1-10. http://dx.doi.org/10.15178/va.2010.113.1-16

Parejo, M., \& Martín-Pena, D. (2011). OndaCampus Radio: Integradora y formadora. En J.J. Aguaded \& P. Contreras (cords), La radio universitaria como servicio público para una ciudadanía democrática. (131-142). A Coruña: Netbiblo.

Piñeiro, M. T., \& Ramos, F. (2011). Potencialidades educativas de las webradios universitarias: Una aproximación desde la perspectiva de docentes y discentes. REDMARKA UIMA-Universidad de A Coruña - CIECID, (6), 85-112.

Sauls, S. J. (1995). College Radio: 10 points of Contention from the Management Perspective. ED410628.

Ugarte, J. (2005). La radio universitaria como medio de aprendizaje. La experiencia de Santo Tomás FM. Emisora de la 
escuela de periodismo de la Universidad de Santo Tomás- Chile. Paper presented at the Second ICongreso Iberoamericano de Comunicación Universitaria, Universidad de Granada, España.

Van der Graaf, L. (2001). Radios Estudiantiles Europeas: Análisis comparativo de emisoras estudiantiles en Francia, Gran Bretaña, Bélgica y España. San José: Universidad de Amsterdam, Universidad de Costa Rica, Radio U.

Vázquez, M. (2010). Jóvenes y Radio Universitaria: un cercamiento a las estrategias formativas de dos países. Resultados de la encuesta; La participación juvenil en radiodifusoras universitarias de México y España. Paper presented at the Second Congreso Internacional de la Asociación Española de Investigadores de la Comunicación (AE-IC), Málaga, España.

Vázquez, M. (2012). La radio universitaria en México y España. Estudio de la participación y formación de los jóvenes (Doctoral Thesis, Universitat Pompeu Fabra, Bacelona, España). http://www.tdx.cat/handle/10803/84113

This work is licensed under a Creative Commons Attribution 3.0 License. 